\title{
A COMPARATIVE STUDY OF THE LEGAL FRAMEWORKS FACILITATING INDIGENOUS LAND MANAGEMENT IN POSTCOLONIAL SOCIETIES: INDIGENOUS AUSTRALIA AND INDONESIAN ADAT LAW
}

\author{
Carly Boag ${ }^{1}$
}

\begin{abstract}
Indigenous Land Management (ILM) promotes environmental justice by "protecting and fulfilling of human rights through legal empowerment of people"50 through meaningful participation in environmental decision making from a regional to an international scale, acknowledgment of cultural differences and the equal distribution of environmental benefits $^{51}$. This paper presents a comparative study on Australia and Indonesian practice of ILM. Although there are historical, cultural and economic differences between Australia and Indonesia as well as different legal ideologies, a comparative study of the different legal frameworks surrounding ILM will provide an insight into the benefits and limitations of divergent policy strategies and the best way forward for Indigenous peoples in the Asian-Pacific region. While development on both countries on ILM practice can be seen as positive steps towards effective ILM, however, much remains to be done to achieve environmental justice for the worlds Indigenous people.
\end{abstract}

Keywords: Indigenous, comparative study, Australia and Indonesia

\section{INTRODUCTION}

Indigenous Land Management

(ILM) encompasses traditional

philosophies and practices of Indigenous people with contemporary scientific techniques to help improve the management and conservation of

\footnotetext{
1 Student of Law School, Faculty of Law, Humanity and Arts, University of Wollongong ${ }^{2}$ Nyoman Nurjaya, 'Access to ecological justice for the marginalised people of Indonesia: Is it a genuine or pseudo recognition and protection?' (Paper presented at International Conference on "Access to Justice: Promoting Public Awareness, Participation and Action”, Brawijaya University East Java, $10^{\text {th }}$ to $11^{\text {th }}$ November 2015) 1.
}

ecosystems. An effective legal framework for ILM promotes environmental justice by "protecting and fulfilling of human rights through legal empowerment of people"4 through meaningful participation in environmental decision making from a regional to an international scale,

\footnotetext{
${ }^{3}$ Nurjaya, above n, 1, 1-11.

${ }^{4}$ Nyoman Nurjaya, 'Access to ecological justice for the marginalised people of Indonesia: Is it a genuine or pseudo recognition and protection?' (Paper presented at International Conference on "Access to Justice: Promoting Public Awareness, Participation and Action”, Brawijaya University East Java, $10^{\text {th }}$ to $11^{\text {th }}$ November 2015) 1.
} 
acknowledgment of cultural differences and the equal distribution of environmental benefits ${ }^{5}$. Both Indonesia and Australia were colonised by European powers with devastating effects on the Indigenous people. Since the 1980's there has been increasing international attention surrounding the lack of environmental justice accessible to Indigenous peoples around the world. Regional, national and international legal frameworks are in place in both Australia and Indonesia to promote globally recognized concepts of ILM, however there is a need for more cohesive and integrated approach at all levels of environmental governance.

Although there are historical, cultural and economic differences between Australia and Indonesia as well as different legal ideologies, a comparative study of the different legal frameworks surrounding ILM will provide an insight into the benefits and limitations of divergent policy strategies and the best way forward for Indigenous peoples in the Asian-Pacific region. This paper presents a comparative study on

\footnotetext{
${ }^{5}$ Nurjaya, above n, 1, 1-11.

${ }^{6}$ Marett Leiboff \&Mark Thomas, Legal Theories Contexts and Practices (Thomas Reuters Australia, $2^{\text {nd }}$ ed, 2014).
}

Australia and Indonesian practice of ILM. While development on both countries on ILM practice can be seen as positive steps towards effective ILM, however, much remains to be done to achieve environmental justice for the worlds Indigenous people.

\section{RESULT AND DISCUSSION}

\section{Post Colonial Legal Analysis}

As law is fundamentally a form of ideology, social and political interactions between human and the natural environment cannot be ignored in environmental policy. Postmodern analysis of law rejects the positivist view that law is separate from the society in which it operates ${ }^{6}$. Law is inherently a social and political entity and can never be a completely autonomous institution. There has recently been greater research into community based resource management and a stronger recognition that social actions and human interactions with the environmental can play an important role in conservation ${ }^{7}$. However there are significant social and

\footnotetext{
${ }^{7}$ Sue Jackson 'Compartmentalising Culture: The Articulation and Consideration of Indigenous Values in Water Resource Management' (2006) 37(1) Australian Geographer 19.
} 
cultural barriers to ILM manifested in national and regional legal frameworks that either obstruct Indigenous tradition and culture often through restricting land rights and traditional economic activities.

The postmodern concept of binary opposites is also an important insight into the barriers inherent in the Western environmental government frameworks. Derrida (2004) argues that binary opposites exist in the Western legal system where the dominant, often Western form governs the supposedly inferior form ${ }^{8}$. In the context of ILM binary opposition exists between modern scientific knowledge and traditional ways of knowing, as well as between the human and natural environments. Indigenous philosophies of land management traditionally revolve around stewardship or eco-centric values and deeply entwine the environment, cultural identity and community. This is in direct contrast to Western anthropogenic views of nature as a resource to be exploited for individual benefit. Scientific or western forms of

\footnotetext{
${ }^{8}$ Jacques Derrida Positions ( $2^{\text {nd }}$ ed, Continuum London, 2004).

${ }^{9}$ Ines Ayari 'The Dynamic between indigenous rights and environmental governance: A preliminary analysis and focus on the impact of
}

knowledge are just one form of understanding of the environment. Sustainable and equitable development for future generations cannot be achieved if only egocentric utility-based views of natural resources are implemented in management policy.

\section{International Framework for ILM}

The international community has recognised that different groups of Indigenous people globally have strong spiritual ties to their natural environment and have practiced sustainable management of various ecosystems for years of generations. Since the 1980's Indigenous people have relatively began to actively participate in United Nations (UN) Human Rights discussions and their concerns have gained increasing international attention ${ }^{9}$. International frameworks on the rights of Indigenous people are extremely broad and there are relatively few conventions and declarations that relate specifically to the implementation of governance structures for ILM. The UN Universal Declaration on Human Rights and the International

\footnotetext{
climate change governance through the Reducing Emissions from Deforestation and Forest degradation (REDD) programme' (2014) 10(1) International Journal of Indigenous Peoples 81.
} 
Convention on the Elimination of all Forms Racial Discrimination form an important basis for Indigenous rights in Australia and Indonesia, the more specific provisions discussed are useful for providing guidance on ILM standards and values accepted by the global community ${ }^{10}$.

The first specific Convention on Indigenous peoples rights was the 1989 International Labour Organisation's Convention Concerning Indigenous and Tribal Peoples in Independent Countries. The convention embodied a paternalistic approach to ILM stating that "governments shall have the responsibility for developing, with the participation of the peoples concerned, coordinated and systematic action to protect the rights of these peoples."11 This legally binding convention was not ratified by any South East Asian country including Australia and Indonesia. The current international law framework has shifted to a self determination approach embodied in the 2007 UN Declaration

${ }^{10}$ Garth Nettheim et al Indigenous Peoples and Governance Structures: A Comparative Analysis of Land and Resource Management Rights (Aboriginal Studies Press for The Institute of Aboriginal and Torres Strait Islander Studies, 2002).

11 International Labour Organisation Convention concerning Indigenous and Tribal Peoples in Independent Countries Convention on the Rights of Indigenous Peoples (UNDRIP). The UNDRIP general assembly adopted the principle of recognition that respect of "Indigenous knowledge, cultures and traditional practices contributes to sustainable and equitable development and proper management of the environment. ${ }^{12}$ " Further article 29(1) of the declarations states that "Indigenous peoples have the right to the conservation and protection of the environment and the productive capacity of their lands or territories and resources. ${ }^{13}$ " Although Australia initially voted against the adoption of the Declaration, both Australian and Indonesia have recognised the declaration. Although the UNDRIP is non-binding it sets important global standards for the implementation of policies relating to Indigenous people "based on proper respect for the rights of Indigenous peoples in terms of their own law, traditions and culture"14 moving towards contemporary post-colonial legal structures.

opened for signature 17 June 1989, No. 169 (Entered into force 05 September 1991) Art 2.

12 United Nations Declaration on the Rights of Indigenous Peoples, GA Res 61/295, UN GAOR, $61^{\text {st }}$ sess, $107^{\text {th }}$ plen mtg, Supp No 49, UN Doc A/RES/61/295 (13 September 2007).

${ }^{13}$ Ibid, Art 29(1).

${ }^{14}$ Nettheim et al, above $n 7$. 
Participation of Indigenous people in environmental management and the ability to participate in sustainable development is emphasised in the 1992 Rio Declaration on the Environment and Development. Principle 22 of the declaration recognises that, "Indigenous people and their communities...have a vital role in environmental management and development due to their knowledge and traditional practices. States should recognise and duly support their identity, culture and interests and enable their effective participation in the achievement of sustainable development. ${ }^{15}$ " Although it is nonbinding, the Rio Declaration reaffirms and expands upon the principles of the first UN Conference on the environment, namely the 1972 Stockholm Declaration.

The 1999 Rio Conference aimed to draw broad human rights concepts into more specific standards in relation to ILM adopting Agenda 21 in the Programme of Action for Sustainable Development which states that "national

15 Rio Declaration on Environment and Development, UN Doc /CONF.151/5/Rev 1 (12 August 1992) Principle 22.

16 Rio Declaration on Environment and Development, UN Doc /CONF.151/5/Rev 1 (12 August 1992) Agenda Item 21 ch 26 art 26(1). and international efforts to implement environmentally sound and sustainable development should recognise, accommodate, promote and strengthen the role of indigenous people and their communities. ${ }^{16}$ " The 1993 UN Convention on Biological Diversity (UNCBD) opened for signing at the Rio Conference is a legally binding agreement that carries international obligations for signatories. The UNCBD requires participants to "protect and encourage customary use of biological resources in accordance with traditional cultural practices that are compatible with conservation or sustainable use requirements"17 and to "preserve knowledge, innovation and practices of indigenous and local communities embodying traditional lifestyles relevant for the conservation and sustainable use

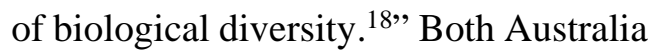
and Indonesia attended the Rio Conference and are signatories to the UNCBD.

\footnotetext{
${ }^{17}$ The United Nations Convention on Biological Diversity opened for signature 5 June 19921760 UNTS 79, 31 ILM 818 (entered into force 29 December 1993) art 10.

${ }^{18}$ Ibid, Art 8.
} 
International governance strategies relating to ILM are comparatively fragmented in their regulation and implementation. UN declarations on the environment are also criticised for being unenforceable "soft law" with a lack of accountability for breaches to the international community. Issues with global international framework are inherent in the structure of international law as a “top down” approaches overlooking the often very specific nature of the environmental management challenges faced by local Indigenous communities $^{19}$. Not all Indigenous peoples want the same institutional structures and negotiation must take place to develop accepted international standards into a more regional context ${ }^{20}$. This is also an issue due to the significant barriers to the active involvement of Indigenous people in the development international environmental governance strategies. This in part has attempted to be overcome by the UN establishment of the Permanent Forum for Indigenous People in $1997^{21}$ to allow Indigenous groups to participate directly rather then

\footnotetext{
${ }^{19}$ Ayari, above $\mathrm{n} 6$.

${ }^{20}$ Nettheim et al, above $n 7$.

18 Permanent Forum Within the United Nations Systems for Indigenous Peoples, CHR Res
}

through national delegates, in international discussions on human rights and environmental governance.

\section{Australia: Aboriginal and Torres Strait Islander People}

British imperial policy in Australia was based on the false legal concept of terra nullius, which denied Indigenous Australians any right to their traditional lands that they had inhabited for thousands of years prior to colonization. The Australian Royal National Park was established in 1879 following the American 'Yellowstone Park' model of conservation, emphasizing Western Romantic paradigms of 'wilderness' constructing a dualism between the human world and natural environment. These binary opposites were framed in environmental management legislation inherently disadvantaging indigenous participation in environmental governance. Indigenous Australian's were not recognised as citizens in the Australian Constitution until 1967 when the so called "Race Power" Section 51(xxvi)

1997/30, ESCOR Supp No 3, UN Doc E/CN4/1997/30 (11 April 1997). 
was amended to allow to Government to make special laws for any race for the "peace, order and good government ${ }^{22 "}$. The Torres Islander Commission recommends that the Constitutional framework must recognise Aboriginal and Torres Strait Islander people as the first people of the Nation and enshrine the goal of overcoming disadvantages faced due to past discrimination ${ }^{23}$.

Australia began to implement joint management strategies in the Northern Territory (NT) in 1976 with the establishment of the Northern Land Council under the Aboriginal Land Rights (Northern Territory) Act $1976^{24}$ in order to conserve national resources whilst recognising traditional land rights of Indigenous people. However the legislation was implemented inconsistently among states and territories. Australian Indigenous people have been able to claim Native Title over Crown Land and National Park areas since the High Court abolished of the

${ }^{22}$ Australian Constitution s 51(xxvi)

${ }^{23}$ Zia Akhtar 'Aboriginal Determination: Native Title Claims and Barriers to Recognition' (2011) 7(2) Law Environment and Development Journal 132.

${ }^{24}$ Aboriginal Land Rights (Northern Territory) Act 1976 (Cth).

${ }^{25}$ Mabo v Queensland (No. 2) 1992175 CLR 1

'Mabo Decision'. concept of terra nullius after the 1992 Mabo Decision ${ }^{25}$ resulting in the implementation of the Commonwealth Native Title Act $1993^{26}$ to recognise and protect Indigenous native title rights. Initially ratifying Australia's international obligations into domestic law was complicated by a lack of specific Constitutional reference to the environment ${ }^{27}$. International treaties and conventions gain their Constitutional legitimacy from the "External affairs" power Section 51(xxix), which was interpreted broadly after the Tasmanian Dams Case $^{28}$ in 1983 allowing the Commonwealth to enact environmental legislation in accordance with International environmental obligations.

Despite this relatively recent recognition of Indigenous customary laws, decolonisation in Australia's context has not seen a return of legal autonomy to Indigenous Australians. The legitimacy of the Indigenous laws has not been recognised, rather customary laws such as native land title

\footnotetext{
${ }^{26}$ Native Title Act 1993 (Cth).

${ }^{27}$ Donald Anton, Jennifer Kohout \& Nicola Pain 'Nationalizing Environmental Protection in Australia: The International Dimensions’ (1993) 23 Environmental Law 763.

${ }^{28}$ Commonwealth v Tasmania (1983) 158 CLR 1.
} 
have been incorporated into the dominant western common law system. This attempt to codify customary laws inherently modifies Indigenous cultural values to subsist within western legal ideologies $^{29}$ diminishing the cultural legitimacy and significance of the laws. There are arguments that a system of legal pluralism in Australia would be more appropriate to recognise customs and Indigenous values such as in the context of caring for country that are not able to be effectively legislated on in the western common law system due to a lack of understanding of cultural norms and beliefs. A shift from Commonwealth governance to legal autonomy has not been readily accepted by the Australian government in the implementation of the UNDRIP and has drawn criticism from the international community.

However since the 1990's Australia's legislative framework for ILM has actively sought to increase Indigenous participation in environmental conservation and development. As The National

${ }^{29}$ Leiboff \& Thomas, above n 3, 505.

${ }^{30}$ International Union for the Conservation of Nature (IUCN), IUCN Protected Categories System (15 January 2014) <http://www.iucn.org/about/work/programmes/ gpap_home/gpap_quality/gpap_pacategories/>. framework has also been guided by the International Union for the Conservation of Nature (IUCN) Guidelines for Applying Protected Area Management Categories, which are recognised by the UN as global standards for incorporating ILM strategies into government legislative frameworks ${ }^{30}$. Management of the area complies with principles of IPA as well as the IUCN as a Category II protected area. Category II areas are "large natural sites set aside to protect large scale ecological processes” and ecosystems "which also provide a foundation for environmentally and culturally compatible ${ }^{31}$ ” opportunities. The core principles of ILM strategies are to integrate the protection of the environment as well as cultural knowledge, such as by providing opportunities for the education of younger generations of Indigenous people.

The Intergovernmental Agreement on the Environment was entered into by all levels of Australian government in 1992 as a non-binding

\footnotetext{
${ }^{31}$ International Union for the Conservation of Nature (IUCN), IUCN Protected Categories System (15 January 2014) <http://www.iucn.org/about/work/programmes/ gpap_home/gpap_quality/gpap_pacategories/>.
} 
agreement acknowledging that

Australia's international obligations fall under Commonwealth jurisdiction, whilst more specific management plans for natural resource management are a state and territory responsibility. ${ }^{32}$ Australia's environmental governance therefore operates under a decentralized legal system. An effective relationship between State and government authorities and legislation is imperative to ensure a cohesive and consistent approach to ILM strategies. Australia's central legislation facilitating ILM, the Commonwealth Environment Protection and Biodiversity Conservation Act 1999 (EPBC) was developed following these intergovernmental discussions. The EPBC supports traditional native title rights under the Native Title Act 1993. The specific state and territory provisions are beyond the scope of the essay.

The EPBC Act aims to implement a nationally integrated approach for states and territory to

32 Ben Boer \& Stefan Gruber, Legal Framework for Protected Areas: Australia, International Union for the Conservation of Nature Environmental Policy and Law Paper No 81 (2010).

${ }^{33}$ Ibid.

34 Jessica Reider 'An Evaluation of Two Environmental Acts: The National administer conservation legislation at a more regional level under the act due to Constitutional limitations on Commonwealth environmental power ${ }^{33}$. The act consolidated five pieces of federal legislation concerning land management and conservation following the ratification of the UNCBD in 1993. The EPBC aims to provide a cohesive national framework for biological conservation and managing the interactions between humans and the environment for all states and territories ${ }^{34}$. Section 3(1)(d) outlines the EPBC's objective to "to promote a cooperative approach to the protection and management of the environment (f) to recognise the role of indigenous people in the conservation and ecologically sustainable use of Australia's biodiversity and (g) to promote the use of indigenous peoples' knowledge of biodiversity with the involvement of, and in cooperation with, the owners of the knowledge." 35 A strong collaborative approach embodied

Environmental policy Act and the Environment Protection and Biodiversity Conservation Act (2012) 14(1) Asia Pacific Journal of Environmental Law 105.

35 Environment Protection and Biodiversity Conservation Act 1999 (Cth) ss 3(1)(d)(f)-(g). 
in the EPBC aims to provide a legal benchmark for the active participation of Indigenous people in all stages of decision making processes which is key for access to environmental justice for Indigenous Australians.

\section{Co or Joint Management}

The EPBC act specifically implements co or joint management strategies to facilitate the involvement of Indigenous communities within the legal system. Section (2)(g) promotes a partnership approach to environmental protection and biodiversity conservation through (iii) recognising and promoting indigenous peoples' role in, and knowledge of, the conservation and ecologically sustainable use of biodiversity. Under co-management plans traditional land is leased back to the government in order to implement and fund conservation plans based on both Indigenous knowledge and scientific conservation practices. The Act also established the Indigenous Advisory Committee under section 505A to advise the Federal Minister for the Environment on the operation of the

\footnotetext{
${ }^{36}$ Ibid, s 505A.

${ }^{37}$ Arturo Izurieta et al 'Developing Indicators for Monitoring and Evaluating Joint Management
}

Act taking into account Indigenous knowledge of land management. ${ }^{36}$

These legal structures aim to incorporate the interests of Indigenous and Non-Indigenous interests with shared access to resources and environmental responsibility. This can cause conflict with governmental goals of biological conservation as ideas of what effective management involves for a particular area may differ. Management plans implemented must take such important cultural objectives into account in order to reconcile these ideological differences in a way that is most beneficial for the conservation of biological and habitat diversity ${ }^{37}$.

\section{Indigenous Protected Areas}

One of Australia's most important ILM strategies is the establishment of Indigenous Protected Areas (IPA) first established in South Australia in 1998. An IPA is defined as "an area of land over which the Indigenous Custodians have entered into a voluntary agreement with the Australian government for the purposes of promoting biodiversity and cultural

Effectiveness in Protected Areas in the Northern Territory' (2011) 16(3) Australia, Ecology and Science 9. 
resource conservation. ${ }^{38 \text { ” }}$ These types of management plans are internationally recognised under the UNCBD as Indigenous and Community Conserved Areas (ICCAs) meeting Australia's international obligations under the declaration and are also in line with ICUN guidelines ${ }^{39}$.

The basis for these areas is not found in any legislation but is completely based in contract law ${ }^{40}$ between Indigenous communities and the Australian government. This allows Indigenous communities to design through collaboration with environmental agencies their own autonomous management plans on freehold title land claimed under the Native Title Act, in accordance with international frameworks. Today there are 60 IPA's that account for $36 \%$ of Australia's National Reserve Areas ${ }^{41}$. This form of legal autonomy creates unique difficulties as it is completely

38 Australian Government Department of the Environment, Water, Heritage and the Arts, The Indigenous Protected Area Program: Background Information and Advice to Applicants (2009) Australian Government Department of the Environment $<$ http://www.environment.gov.au/indigenous/pu bs/ipa/ipa-advice.pdf>.

39 Helen Ross et al 'Co-management and Indigenous Protected Areas in Australia: Achievements and ways forward' (2009) 16 independent from the EPBC Act. There is currently no government framework for monitoring the conservation success of IPA's. A cohesive framework in line with the EPBC goals needs to be implemented in federal legislation, to avoid land use conflicts at a regional level $^{42}$. However this creates the paradox that an assessment of success implemented in federal legislation will inherently be from a western postcolonial perspective.

The clear legislative processes to establish co-management strategies and IPA's under the EPBC framework allows Indigenous people to develop greater autonomy alongside meaningful legal recognition of the importance of traditional knowledge for natural resource conversation. The success of the legislative framework has resulted in the expansion of Australia's system of National Reserve Areas. Although there are significant socio-economic barriers

\footnotetext{
Australasian Journal of Environmental Management 242.

${ }^{40}$ Nicholas Goldstein, 'Indigenous Land Rights in National Parks: The United States, Canada and Australia compared' (2013) 9(2) Macquarie Journal of International and Comparative Environmental Law 65, 81.

${ }^{41}$ Ibid.

${ }^{42}$ Benxiang Zeng \& Rolf Gerristen, 'Key Issues in Management of Indigenous Protected Areas: A Perspective from Northern Australia' (2015) 8(3) Global Studies Journal 19.
} 
to participation in ILM plans in practice, the current legal framework has been a positive step towards the empowerment of Indigenous communities to care for their country according to customary law.

Robinson et al. (2014) found that whilst Indigenous organisations are highly interested in actively engaging in ILM projects, they often face key barriers to participation that need to be addressed in order to achieve the maximum ecological and cultural benefits possible from contemporary ILM strategies ${ }^{43}$. Information needs to be readily available to Indigenous organisations to support their decision making process when assessing how their community can most effectively become involved in the management of the land and how to incorporate their ecological knowledge into contemporary conservation programs. Power imbalances and socio-economic disadvantages experienced by Indigenous Australians also create the danger of the dominant roles of

${ }^{43}$ Cathy Robinson et al 'Australia's Indigenous Carbon Economy: A National Snapshot' (2014) 52(2) Geographical Research 123.

${ }^{44}$ Ibid.

${ }^{45}$ Luke Arnold, 'Deforestation in Decentralised Indonesia: What's Law Got to Do With it?' 4(2) Law Environment and Development Journal 77. education and land management both being fulfilled by the government or other powerful stakeholders such as corporations, rather then the Indigenous land owners ${ }^{44}$. The Australian government must be careful to include Indigenous leadership in all stages of the legislative decision making, legal monitoring, recommendations and law reform.

\section{Indonesia: Adat Communities}

Indonesia is home to some of the biologically richest forests in the world. Timber industries are vital to Indonesia’s economic development with around 30 million Indonesian people also rely on these forests for their livelihood. ${ }^{45}$ Adat broadly refers to customary laws of different Indigenous groups and is one of the three components of legal plurality in Indonesia alongside Civil Law and Sharia Law. Adat law is "a complex of rights and obligations tying together history, land a law in a specifically Indonesian way, ${ }^{46}$ " there are no uniform Adat laws as every locality has culturally

\footnotetext{
${ }^{46}$ Jamie Davidson \& David Henley, The Revival of Traditional in Indonesian Politics. The Deployment of Adat from Colonialism to Indigenism (Routledge Contemporary Southeast Asia Series, $1^{\text {st }}$ ed, 2007) 377.
} 
specific rules to meet the needs of the community.

Indigenous people in South-East Asia face significant and pressing challenges in relation to environmental justice and human rights abuses. Despite this Indigenous groups in developing countries such as the Indonesian Adat people are unable to maintain active involvement in international discussions on Indigenous issues ${ }^{47}$. The Dutch colonisers in Indonesia favoured forest management based on Modernism and Enlightenment ideas of science and logic as supreme. Adat communities who traditionally live in forest areas on remote islands in the Indonesian archipelago rely on ecological resources for their local economy and livelihoods. These communities were believed by the Dutch to be responsible for forest destruction, a stereotype that is still widely held throughout South East Asian countries today. ${ }^{48}$ It has become clear that Indonesian laws need to empower Indigenous communities to assist the

${ }^{47}$ Alexandra Xanthaki, 'Land Rights of Indigenous Peoples in South-East Asia’ (2003) 4(2) Melbourne Journal of International Law 467.

${ }^{48}$ Arnold, above n 42..

49 Marett Leiboff \&Mark Thomas, Legal Theories Contexts and Practices (Thomas Reuters Australia, $2^{\text {nd }}$ ed, 2014) 503. government in curbing the alarming deforestation occurring due to the sheer size and biomass of the forest ecosystems.

In contrast to Australia, Indonesia underwent decolonisation to a greater extent, developing a pluralistic legal system after its independence from Dutch rule in 1945. The post-colonial legal systems that developed are "neither an imprint left by the departed colonial power, nor a resurrected form of the precolonial culture. ${ }^{49}$ " Remote islands in Indonesia maintained governance by customary Adat Law and maintained legal autonomy to the degree that it did not interfere with state economic interests. This autonomy was enshrined in the 1945 Indonesian Constitution and a system of legal pluralism was created.. Indonesia has a system of weak legal pluralism with customary laws recognised inconsistently and placed under significant state restrictions. ${ }^{50}$

In 1950 when the newly established federal system was replaced

\footnotetext{
50 Hilaire Tegnan 'Legal Pluralism and land administration in West Sumatra: The Implementation of the Regulations of both Local and Ngari Governments on Communal Land Tenure’ (2015) 47(2) Journal of Legal Pluralism and Unofficial Law 312.
} 
with the Unitary State of Indonesia, under the first President Sukarno and the post-colonial government ironically inherited the Dutch scientific based forestry management approach. ${ }^{51}$ After the fall of President Suharto in 1998 Indonesia has undergone a major period of law reform known as the 'Reformation Era'. Environmental law reform focused on calls for decentralisation of environmental management provisions from central to regional governments and a greater recognition of Adat rights to natural resources $^{52}$. However this has lead to renewed uncertainty about the role and of Adat law in Indonesia and in practice has not lead to increased involvement of Indigenous people in forest management.

\section{Constitutional Recognition}

The Indonesian Ideology of the State that provides the basis for the legal framework for recognition of customary law and environmental management is established in the 1945 Republic of

\footnotetext{
51 Arnold, above n 42.

52 Tegnan, above n 47.

53 Undang-Undang Dasar Republik Indonesia 1945 [Constitution of the Republic of Indonesia 1945] (Indonesia) Premable [author's trans].

${ }^{54}$ Nyoman Nurjaya, 'Ideology of the State in controlling and managing natural environmental and resources: Its Implication to national law
}

Indonesia Constitution. The preamble establishes that state can control natural resources to "enhance prosperity and peoples welfare... ${ }^{53}$ " This national development model is the basis of Indonesian environmental policy. State based resource management is implemented for the central purpose of economic growth development ${ }^{54}$. Article 3 of the Constitution further codifies this economic commodity ideology, stating that "the earth and water and natural resources contained therein should be controlled by the State and shall be utilized for greatest prosperity of the

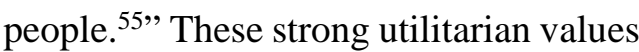
embedded in the Constitutional framework are in fact be the source of the greatest disadvantage to minority people namely the Adat communities of remote Indonesia.

In contrast to the historical context of Australia the Adat people were immediately Constitutional recognition of their customary rights. Ironically it is this recognition that

development' (Paper Presented at International Conference on Sumatera Ecosystem Restoration in Comparison: Lesson Learned and Future Challenges, Andalas University Padang, West Sumatera, $24^{\text {th }}$ to $25^{\text {th }}$ October 2011).

55 Undang-Undang Dasar Republik Indonesia 1945 [Constitution of the Republic of Indonesia 1945] (Indonesia) art 33(3) [author's trans]. 
provides the greatest hurdle to Indigenous participation in forestry management. The Constitution sets specific conditions and restrictions for the recognition of Adat laws. Article 18B paragraph (2) of the Constitution states that "the state recognises and respects the Adat communities and their traditional rights as long as these remain in existence, and are in accordance with the societal development... ${ }^{56 ”}$. Nurjaya (2015) believes that this condition creates "pseudo recognition" of customary law restricting the capacity of Adat communities to actively participate in environmental management of their traditional lands ${ }^{57}$.

Despite being a signatory to the Rio Declaration and the legally binding UNCBD, international standards of the protection of Indigenous traditional activities in Indonesia are subsistent to the interests of the state. Economic development is valued in the legal framework above environmental and cultural conservation. This pseudoconstitutional ideology enables the state to "systematically ignore and neglect the

56 Undang-Undang Dasar Republik Indonesia 1945 [Constitution of the Republic of Indonesia 1945] art 18B(2) (Indonesia) [author's trans].

${ }^{57}$ Nurjaya, above n, 1, 6. living customary law as a legal entity in the total system of Indonesia's national law ${ }^{58}$." The words “as long as” in article 18B effectively creates a legal framework for the corporate exploitation the rich natural resources of Indonesia's tropical forests by transnational corporations at the expense of the environment and the livelihood of Indigenous people.

Customary law controls the sustainable management of the natural resources on which Adat communities depend on for their livelihood. Adat communities believe that a "right to land does not necessarily include any right to development of that land ${ }^{59 "}$ and contain provisions about harvesting of forest materials and hunting of rare fauna to ensure the regeneration of natural resources. ${ }^{60}$ "Indigenous forest management is not recognised as a viable practice for wildlife and environmental conservation.”61 These ideological differences between Adat law and the Civil Code add to disputes over which law applies between Indigenous people and the state. Where contrary interests

\footnotetext{
${ }^{58}$ Nurjaya, above n, 1, 9.

${ }^{59}$ Supreme Court of Indonesia (ed), Indonesian Legal System 'Lecture 2 Readings' (2005) 39.

${ }^{60}$ Arnold, above n 42.

${ }^{61}$ Xanthaki, above n 44.
} 
exist the state law prevails due the conditions placed on recognition of Adat Law.

\section{State Laws}

The Indonesian state civil code under the Constitutional framework plays a major role in facilitating environmental degradation. Adat law recognises two types of customary land rights, communal and individual ownership, similar to Native Title in Australia. The Basic Agrarian Law 1960 (BAL) extinguished many land rights based on Adat Law in an attempt to unify all types of Indonesian land law. BAL emphasises a western system of registering land title incompatible with traditional oral systems based on local knowledge ${ }^{62}$.

The current Forestry Act, Law No. 41 Year 1999 specifically mentions Article 33(3) in its preamble as one source of its Constitutional legitimacy, indicating its underlying economic development ideology. Despite being implemented in response to principles of the Rio Declaration the law unfortunately represents a step backward

\footnotetext{
${ }^{62}$ Kallie Szczepanski 'Land Policy and Adat Law in Indonesia’s Forests’ (2002) 11(1) Pacific Rim Law and Policy Journal 231.

63 Ibid, 244.
}

for the recognition of Indigenous land rights and does not facilitate any meaning participation of Indigenous people in forestry management ${ }^{63}$. The Act does not contain a provision outlining the process for the recognition of Adat land rights under the Act. Whilst Article 67(1) does indicate some recognition of principles of ILM, stating "where Adat communities are registered by state they are able to "collect forest produce to fulfil daily needs of relevant customary law community” and are able to (b) "manage forests according to the prevailing indigenous law and not incontravention of the law”. ${ }^{64}$ This allows Adat laws to be undermined by National laws clearly biased towards transnational corporations in the interest of economic development providing an extremely insecure basis for the recognition of Adat laws.

The Forestry Law seems to be an attempt to reconsolidate the federal government's power in relation to forest management with the role of regional government and customary law largely ignored $^{65}$. Article 61 provides that all

\footnotetext{
${ }^{64}$ Basic Forestry Law No. 411999 (Indonesia) Art 67(1)(a)-(b).

${ }^{65}$ Arnold, above n 42.
} 
regional management and any decentralisation of provisions should be monitored and regulated by federal legislation (Article 66) ${ }^{66}$. This top-down approach to land management is contrary to the national goals of law reform and decentralisation, taking power away from regional and local governance structures including Adat law. In a system of legal pluralism centralisation this can operate to dominate other less authoritative sub-systems of law. This has lead to a situation where both the central and state governments are able to use their power to exploit forests and neither are under any obligation to claim any responsibility for sustainable management ${ }^{67}$. These laws becomes "an expression of the State's authority and legitimacy to control resources tenure and management ${ }^{68}$ " for the economic development of Indonesia.

The 2007 UN Committee on Elimination of Racial Discrimination noted that the legal frameworks for the recognition of customary laws do not provide "appropriate safeguards

\footnotetext{
${ }^{66}$ Basic Forestry Law No. 411999 (Indonesia) Arts 61, 66.

${ }^{67}$ Arnold, above n 41, 91.

${ }^{68}$ Nurjaya, above n 50.

${ }^{69}$ United Nations Committee on the Elimination of Racial Discrimination, Seventy-first session:
}

guaranteeing respect for the fundamental principle of self-identification in the determination of indigenous peoples. ${ }^{69}$, The complex and uncertain application process and cost of legal procedures to apply for recognition effectively removes the function of ILM in Indonesia’s forests conservation. Quasijudicial recognition of Adat councils with decentralised policy power over certain aspects of forest management ${ }^{70}$ could help Indigenous communities attain greater legal power to assert their customary land title rights over transnational corporations. There is also a lack of political motivation to implement effective legislative change with assertions that the legal framework does not require any further amendment despite entrenched ideological flaws ${ }^{71}$. Although there are significant challenges faced due to a lack of resources for the implementation and enforcement of environmental laws, these issues should be analysed in conjunction with the limitations of the Constitutional framework.

Concluding observations of the Committee on the Elimination of Racial Discrimination Indonesia, Doc CERD/C/IDN/CO/ 3 (15 August 2007) 15.

${ }^{70}$ Arnold, above n 42, 98.

${ }^{71}$ Arnold, above $n$ 42, 78. 
Indonesia's system of weak legal pluralism has created pseudo recognition of customary Adat laws and has created significant barriers to any meaningful participation of Indigenous communities in the management of their traditional lands. The Constitutional and State environment governance frameworks whilst undergoing significant reform are designed to support the economic develop of Indonesia at the cost of conservation of Indonesia's rich ecological resources and the loss of Adat culture. The Basic Forestry Laws both passively and actively ${ }^{72}$ support deforestation by not only ignoring the role of Indigenous communities in land management but by also creating legal barriers that marginalise Indigenous people in the legal system. However the willingness of Indonesia to participate in International Declarations on the rights of Indigenous peoples and the Rio Declaration is a positive step demonstrating the willingness of the Indonesian government to work towards greater environmental justice for Adat communities.

${ }^{72}$ Arnold, above $\mathrm{n} 42$.

${ }^{73}$ Haripriya Rangan \& Marcus Lane 'Indigenous Peoples and Forest Management: Comparative Analysis of Institutional Approaches in Australia

\section{Australia's Role in the Asia Pacific}

Despite cultural, social and political differences between Aboriginal and Torres Strait Islander people and Indonesian Adat communities, both face substantive legal barriers to active participation in access to traditional lands and natural resource management due to the continuing impacts of colonisation and experiences of disposition. ${ }^{73}$ Australia is one of the most developed and economically stable countries in the Asia Pacific Region and a world leader in Indigenous land and heritage management. Part of our international environmental obligations are to provide financial and practical assistance to help developing countries, such as Indonesia to successfully develop and implement effective ILM frameworks to ensure Indigenous people attain environmental justice. Principle 24 of the Stockholm Decoration enshrines this principle stating that "bilateral cooperation to effectively control, prevent, reduce, and eliminate adverse environmental effects is necessary. ${ }^{74 \text { " }}$

and India' (2001) 14(1) Society an Natural Resources 145, 148.

${ }^{74}$ Declaration of The United Nations Conference on the Human Environment UN Doc A/CONF.48/14/Rev.1 (1973) art 24. 
This is emphasised in Principle 7 of the Rio Declaration, which acknowledges the responsibility of developed countries to assist developing countries efforts to protect to environment. ${ }^{75}$

Treaties and Action plans specific to the needs of the Asian Pacific Region are an important mechanism for the implementation of ILM plans. 22 of the nations that make up the region are developing countries such as Indonesia that may not have the economic resources to fulfill broad international obligations $^{76}$. The Australian government will invest \$375.7 Million in 2015-16 mainly to improve economic development with the majority of this funding delivered through the Indonesia Australia Comprehensive Economic Partnership Agreement (IA-CEPA) ${ }^{77}$. The Aid Investment Plan (2015-16) does not specifically mention the preservation of Adat culture or the support of ILM strategies and traditional conservation practices.

75 Rio Declaration on Environment and Development, UN Doc /CONF.151/5/Rev 1 (12 August 1992) art 46.

${ }^{76}$ Anton et al, above n 23.

77 Australian Government Department of the Foreign Affairs and Trade, Development Assistance in Indonesia (2015) Australian Government $<$ http://dfat.gov.au/geo/indonesia/development-
Australia’s only environmentally focused bilateral agreement with Indonesia, The Indonesian-Australian Forest Carbon Partnership (IAFCP) was entered into in 2008 under the UN Framework Convention on Climate Change. The agreement was terminated by the Labour government in late 2013 after failing to even attempt to achieve its goal of performance-based payments for the conservation of the forests of Kalimantan $^{78}$. The complete lack of initiatives to support the development of ILM strategies in accordance with International Obligations is overall a failure to the environment and the development of Indigenous peoples as a whole. Australia has not fulfilled it obligations to Indonesia or the AsiaPacific region and more should be done to enhance bilateral and multilateral cooperation for the benefit of Indigenous peoples and environmental conservation in the Asia-specific region and globally.

assistance/pages/development-assistance-inindonesia.aspx $>$.

${ }^{78}$ Robin Davies, The Indonesia-Australia Forest Carbon Partnership: A Murder Mystery, Development Policy Centre Australia < http://devpolicy.org/the-indonesia-australiaforest-carbon-partnership-a-murder-mystery20150610/>. 


\section{CONCLUSION}

ILM principles are increasingly being incorporated into contemporary conservation programs as the broad environmental and cultural benefits of traditional knowledge passed down for thousands of generations, are being formally recognised by the international community. Australia and Indonesia have both moved into a post-colonial legal era and have developed legal frameworks surrounding ILM in response to international principles. However the vastly different systems of legal pluralism in Indonesia and legal centralism in Australia create diverse challenges for the recognition and implementation of traditional conservation strategies based on customary principles and laws. Australia must implement Constitutional recognition of the right to selfdetermination of Indigenous people and ensure the active participation of Indigenous communities in legal reform and development, to overcome past discrimination based on western legal principles. The Indonesian Constitution also needs to undergo an ideological shift from promoting purely economic growth to provide meaningful recognition of Adat law and to meet minimum standards of sustainable development and the rights of Indigenous people. Australia has not met its obligations to the international community and particularly to the Asian-Pacific Region to support the development of effective and inclusive ILM strategies and legal frameworks. Australia has failed to provide any meaningful support through bilateral agreements to Indonesia to assist in the legal reform of environmental laws and policy surrounding the recognition of Customary Law. Although there have been positive steps towards effective ILM regionally and globally there is still a significant amount of progress to be made in order to achieve environmental justice for the worlds Indigenous people.

\section{REFERENCES}

\section{A Articles/Books/Reports}

Akhtar, Zia 'Aboriginal Determination: Native Title Claims and Barriers to Recognition' (2011) 7(2) Law Environment and Development Journal 132 $<$ http://heinonline.org.ezproxy.u ow.edu.au/HOL/Page?handle=h ein.journals/leadjo7\&collection= journals\&page $=132>$

Anton, Donald, Kohout, Jennifer \& Pain, Nicola 'Nationalizing Environmental Protection in Australia: The International 
Dimensions’ (1993) 23

Environmental Law 763

$<$ http://heinonline.org.ezproxy.u ow.edu.au/HOL/Page?handle $=\mathrm{h}$

ein.journals/envlnw23\&collectio

$\mathrm{n}=$ journals\&page $=763>$

Arnold, Luke, 'Deforestation in Decentralised Indonesia: What's Law Got to Do With it?' (2008) 4(2) Law Environment and Development Journal 77 $<$ http://heinonline.org.ezproxy.u ow.edu.au/HOL/Page?handle=h ein.journals/leadjo4\&collection= journals\&page $=75>$

Ayari, Ines, 'The Dynamic between indigenous rights and environmental governance: A preliminary analysis and focus on the impact of climate change governance through the Reducing Emissions from Deforestation and Forest degradation (REDD) programme' (2014) 10(1) International Journal of Indigenous Peoples 81 $<$ http://eds.b.ebscohost.com.ezpr oxy.uow.edu.au/eds/pdfviewer/p dfviewer?sid=b0c3835e-45ec43f9-b97e6fa4b5c5fbc0@sessionmgr112\& vid=7\&hid $=117>$

Benxiang Zeng \& Rolf Gerristen, 'Key Issues in Management of Indigenous Protected Areas: A Perspective from Northern Australia' (2015) 8(3) Global Studies Journal 19 $<$ http://eds.b.ebscohost.com/eds/ pdfviewer/pdfviewer?sid=b0c38 35e-45ec-43f9-b97e6fa4b5c5fbc0\%40sessionmgr11 2\&vid=10\&hid=117>
Boer, Ben \& Gruber, Stefan Legal Framework for Protected Areas: Australia, International Union for the Conservation of Nature Environmental Policy and Law Paper No $81 \quad$ (2010) $<$ https://portals.iucn.org/library/ efiles/edocs/eplp-081.pdf $>$

Davidson, Jamie \& Henley, David The Revival of Traditional in Indonesian Politics. The Deployment of Adat from Colonialism to Indigenism (Routledge Contemporary Southeast Asia Series, $1^{\text {st }}$ ed, 2007)

Derrida, Jacques Positions $\left(^{\text {nd }}\right.$ ed, Continuum London, 2004)

Goldstein, Nicholas, 'Indigenous Land Rights in National Parks: The United States, Canada and Australia compared' (2013) 9(2) Macquarie Journal of International and Comparative Environmental Law 65 $<$ http://heinonline.org.ezproxy.u ow.edu.au/HOL/Page?handle $=\mathrm{h}$ ein.journals/macqjice9\&id=165 \&collection=journals $>$

Hitchner, Sarah 'Heart of Borneo as 'Jalan Tikus': Exploring the Links Between Indigenous Rights, Extractive and Exploitative Industries and Conservation at the World Conservation Congress 2008' (2010) 8(4) Conservation and Society 320 $<$ http://eds.b.ebscohost.com.ezpr oxy.uow.edu.au/eds/pdfviewer/p dfviewer?sid=405462b3-58c24fef-9927- 
8a3b8d019d8a\%40sessionmgr12 0\&vid=5\&hid $=117>$

Izurieta, Arturo, Sithole, Bevlyne, Stacey, Natasha, Hunter-Xenie, Hmalan, Campbell, Bruce, Donohue, Paul, Brown, Jessie \& Wilson, Lincoln 'Developing Indicators for Monitoring and Evaluating Joint Management Effectiveness in Protected Areas in the Northern Territory' (2011) 16(3) Australia, Ecology and Science 9 $<$ http://eds.b.ebscohost.com/eds/ pdfviewer/pdfviewer?sid=40546 2b3-58c2-4fef-9927-

8a3b8d019d8a\%40sessionmgr12 0\&vid=8\&hid $=117>$

Jackson, Sue 'Compartmentalising Culture: The Articulation and Consideration of Indigenous Values in Water Resource Management' (2006) 37(1) Australian Geographer 19 $<$ http://eds.b.ebscohost.com/eds/ pdfviewer/pdfviewer?sid=40546 2b3-58c2-4fef-9927-

8a3b8d019d8a\%40sessionmgr12 0\&vid=11\&hid=117>

Leiboff, Marett \& Thomas, Mark Legal Theories Contexts and Practices (Thomas Reuters Australia, $2^{\text {nd }}$ ed, 2014)

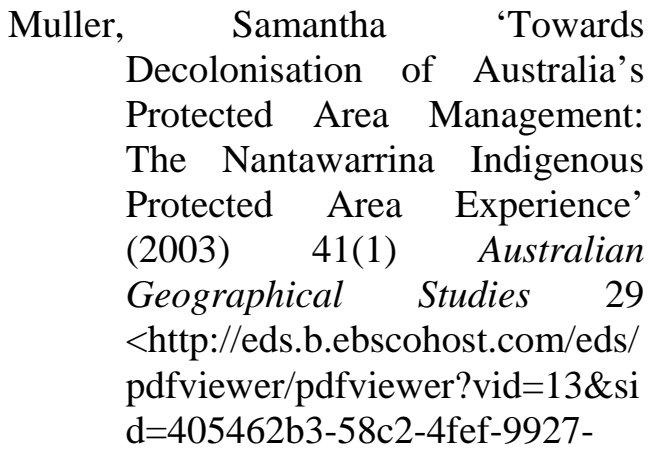

8a3b8d019d8a\%40sessionmgr12 0\&hid=117>

Nettheim, Garth, Meyers, Gary \& Craig Donna Indigenous Peoples and Governance Structures: A Comparative Analysis of Land and Resource Management Rights (Aboriginal Studies Press for The Institute of Aboriginal and Torres Strait Islander Studies, 2002) $<$ http://search.informit.com.au.e zproxy.uow.edu.au/fullText; dn= 408340972336618;res=IELIND $>$

Nurjaya, Nyoman, 'Access to ecological justice for the marginalised people of Indonesia: Is it a genuine or pseudo recognition and protection?' (Paper presented at International Conference on "Access to Justice: Promoting Public Awareness, Participation and Action”, Brawijaya University East Java, $10^{\text {th }}$ to $11^{\text {th }}$ November 2015)

Nurjaya, Nyoman, 'Ideology of the State in controlling and managing natural environmental and resources: Its Implication to national law development' (Paper Presented at International Conference on Sumatera Ecosystem Restoration in Comparison: Lesson Learned and Future Challenges, Andalas University Padang, West Sumatera, $24^{\text {th }}$ to $25^{\text {th }}$ October 2011)

Nurjaya, Nyoman, 'Progressive environmental law of Indonesia: Global principles of Stockholm 
and Rio declarations as defined within the 2009 Act on Human Environmental Protection and Management' (2014) 11(1) USChina Law Review 1

Rangan, Haripriya \& Lane, Marcus 'Indigenous Peoples and Forest Management: Comparative Analysis of Institutional Approaches in Australia and India' (2001) 14(1) Society an Natural Resources 145 $<$ http://wwwtandfonline.com.ezproxy.uow.ed u.au/doi/pdf/10.1080/089419201 300000544>

Reider, Jessica 'An Evaluation of Two Environmental Acts: The National Environmental policy Act and the Environment Protection and Biodiversity Conservation Act' (2012) 14(1) Asia Pacific Journal of Environmental Law $105<$ http://heinonline.org.ezproxy.uo w.edu.au/HOL/Page?handle=hei n.journals/apjel14\&collection $=\mathrm{j}$ ournals\&page $=105>$

Robinson, Cathy, Gerrard, Emily, May, Tracey \& Maclean, Kirsten 'Australia's Indigenous Carbon Economy: A National Snapshot' (2014) 52(2) Geographical Research 123 $<$ http://eds.b.ebscohost.com/eds/ pdfviewer/pdfviewer?vid=29\&si $\mathrm{d}=405462 \mathrm{b3}-58 \mathrm{c} 2-4$ fef-99278a3b8d019d8a\%40sessionmgr12 0\&hid=117>

Ross, Helen, Grant C, Robinson Cathy, Izurieta, Arturo, Smyth D \& Rist, $\mathrm{P}$ 'Co-management and Indigenous Protected Areas in
Australia: Achievements and ways forward' (2009) 16 Australasian Journal of Environmental Management 242 $<$ http://eds.b.ebscohost.com/eds/ pdfviewer/pdfviewer?vid=31\&si d=405462b3-58c2-4fef-9927-

8a3b8d019d8a\%40sessionmgr12 0\&hid=117>

Sakumoto, Naoyuki 'Development of Environmental Law and Legal Reform in Indonesia' in Sakumoto, Naoyuki \& Juwana Hikmahanto (eds), Reforming Law and Institutions in Indonesia: An Assessment (Institute of Developing Economies, Japan External Trade Organisation, 2007) 205

Shearing, Susan, 'Reforming Australia’s National Heritage Law Framework' (2012) 8(1) Macquarie Journal of International and Comparative Environmental Law 71 $<$ http://heinonline.org.ezproxy.u ow.edu.au/HOL/Page?handle $=\mathrm{h}$ ein.journals/macqjice8\&id=77\& collection=journals $>$

Surharno, Dyah \& Friedbery, Claudia, 'Resource Management Issue: NGOs relate to the new legal framework for local autonomy in Indonesia’ (2003) 55(178) International Social Science Journal 573 $<$ http://eds.b.ebscohost.com/eds/ pdfviewer/pdfviewer?sid=40546 2b3-58c2-4fef-9927-

8a3b8d019d8a\%40sessionmgr12 0\&vid=37\&hid=117>

Szczepanski, Kallie 'Land Policy and Adat Law in Indonesia’s Forests' 
(2002) 11(1) Pacific Rim Law and Policy Journal 231 $<$ http://heinonline.org.ezproxy.u ow.edu.au/HOL/Page?handle $=\mathrm{h}$ ein.journals/pacrimlp11\&collect ion=journals \&page $=231>$

Supreme Court of Indonesia (ed), Indonesian Legal System 'Lecture 2 Readings' (2005)

Tegnan, Hilaire 'Legal Pluralism and land administration in West Sumatra: The Implementation of the Regulations of both Local and Ngari Governments on Communal Land Tenure' (2015) 47(2) Journal of Legal Pluralism and Unofficial Law 312 $<$ http://wwwtandfonline.com.ezproxy.uow.ed u.au/doi/full/10.1080/07329113. 2015.1072386\#abstract>

Wright, Glen 'Indigenous People and Customary Land Ownership under Domestic REDD+ Frameworks: Case Study of Indonesia' (2011) 7(2) Law, Environment and Development Journal 119 $<$ http://heinonline.org.ezproxy.u ow.edu.au/HOL/Page?handle $=\mathrm{h}$ ein.journals/leadjo7\&collection= journals\&page=117>

Xanthaki, Alexandra, 'Land Rights of Indigenous Peoples in SouthEast Asia' (2003) 4(2) Melbourne Journal of International Law 467 $<$ http://search.informit.com.au.e zproxy.uow.edu.au/fullText;dn= 20052371;res=AGISPT>

\section{Cases}

Mabo v Queensland (No. 2) 1992175 CLR 1

Commonwealth v Tasmania (1983) 158 CLR 1

\section{Legislation}

$\begin{array}{cr}\text { Aboriginal Land Rights } & \text { (Northern } \\ \text { Territory) Act } & 1976 \\ \text { (Commonwealth) } & \end{array}$

Australian Constitution

Act No 51960 Concerning Basic Regulation for Agrarian Affairs (Indonesia)

Environment Protection and Biodiversity Conservation Act 1999 (Commonwealth)

Law No. 41 of 1999 Act Concerning Basic Forestry (Indonesia)

Native Title Act 1993 (Commonwealth)

Undang-Undang Dasar Republik Indonesia 1945 [Constitution of the Republic of Indonesia 1945] (Indonesia)

Undang-Undang Nomor 4 Tahun 1982 Tentang Ketentuan-Ketentuan Pengelolaan Lingkungan Hidup [Law No 4 of 1982 Act Concerning Basic Human Environment] (Indonesia)

Undang-Undang Nomor 32 Tahun 2009 Tentang Perlindungan dan Pengelolaan Lingkungan Hidup [Law No 32 of 2009 Act Concerning Human Environment Protection and Management] (Indonesia) 
Treaties

Declaration of The United Nations Conference on the Human Environment UN Doc A/CONF.48/14/Rev.1 (1973)

International Labour Organisation Convention concerning Indigenous and Tribal Peoples in Independent Countries Convention, opened for signature 17 June 1989, No. 169 (Entered into force 05 September 1991)

International Convention for the Elimination of All Forms of Racial Discrimination, Opened for signature 7 March 1966, 660 UNTS 195 (entered into force 4 January 1969)

Rio Declaration on Environment and Development, UN Doc /CONF.151/5/Rev 1 (12 August 1992)

Permanent Forum Within the United Nations Systems for Indigenous Peoples, CHR Res 1997/30, ESCOR Supp No 3, UN Doc E/CN4/1997/30 (11 April 1997)

The United Nations Convention on Biological Diversity opened for signature 5 June 19921760 UNTS 79, 31 ILM 818 (entered into force 29 December 1993)

United Nations Declaration on the Rights of Indigenous Peoples, GA Res 61/295, UN GAOR, 61 ${ }^{\text {st }}$ sess, $107^{\text {th }}$ plen mtg, Supp No 49, UN Doc A/RES/61/295 (13 September 2007)

$$
\begin{aligned}
& \text { United Nations Committee on the } \\
& \text { Elimination of Racial } \\
& \text { Discrimination, Seventy-first } \\
& \text { session: Concluding } \\
& \text { observations of the Committee on } \\
& \text { the Elimination of Racial } \\
& \text { Discrimination - Indonesia, Doc } \\
& \text { CERD/C/IDN/CO/ } 3 \text { (15 August } \\
& \text { 2007) }
\end{aligned}
$$

\section{Other}

Australian Government Department of the Environment, Water, Heritage and the Arts, The Indigenous Protected Area Program: Background Information and Advice to Applicants (2009) Australian Government

$<$ http://www.environment.gov.a u/indigenous/pubs/ipa/ipaadvice.pdf $>$

Australian Government Department of the Foreign Affairs and Trade, Development Assistance in Indonesia (2015) Australian Government $<$ http://dfat.gov.au/geo/indonesi a/developmentassistance/pages/developmentassistance-in-indonesia.aspx $>$

Commonwealth Scientific and Industrial Research Organisation (CSIRO), Indigenous Land Management in Australia: A Summary of the Extent, Barriers and Success Factors (2013) $<$ http://www.daff.gov.au/SiteCol lectionDocuments/naturalresources/landcare/submissions/i lm-factsheet.pdf>

International Union for the Conservation of Nature (IUCN), IUCN 
Brawijaya Law Journal V.3 n.2 Contemporary Indigeneous and Constitutional Issues

Protected Categories System (15

January 2014)

$<$ http://www.iucn.org/about/wor

k/programmes/gpap_home/gpap

_quality/gpap_pacategories>

Davies, Robin The Indonesia-Australia

Forest Carbon Partnership: A

Murder Mystery, Development
Policy
Centre
Australia
$<$ http://devpolicy.org/the-
indonesia-australia-forest-
carbon-partnership-a-murder-
mystery-20150610/> 